\title{
EVALUASI KINERJA PEGAWAI UNTUK MEWUJUDKAN PELAYANAN PUBLIK DALAM PERSPEKTIF GOOD GOVERNANCE
}

\author{
Nur Aini \\ Universitas Islam Malang \\ email: aiiniinur58@gmail.com
}

\begin{abstract}
ABSTRAK
Penelitian ini membahas mengenai evaluasi (penilaian) kinerja pegawai yang berkerja pada institusi pemerintah, pada dasarnya institusi pemerintah memiliki tujuan yaitu memberikan pelayanan yang prima kepada masyarakat, selain memberikan pelayanan yang prima kepada masyarakat institusi pemerintah juga ingin mewujudkan tata kelola pemerintahan yang baik (Good Governance). Dengan mengimplementasikan pelayanan yang mudah, cepat, bebas pungli. Adapun Tujuan untuk mengetahui evaluasi kinerja pegawai untuk mewujudkan pelayanan publik dalam perspektif Good Governance. dan faktor pendukung, penghambat dalam pelaksanaan evaluasi kinerja pegawai untuk mewujudkan pelayanan publik dalam perspektif Good Governance. Dalam penelitian ini menggunakan pendekatan kualitatif dan menggunakan jenis deskriptif, penelitian ini juga diperoleh dari hasil wawancara, observasi, dan diperkuat dengan dokumentasi. Dan analisis data yang digunakan yaitu, analisis domain, analisis taksonomi, analisis komponen sial dan terakhir analisis tema budaya. Hasil yang diperoleh pada penelitian ini adalah pelayanan yang diberikan kepada masyarakat cukup baik, walaupun ada hal-hal yang perlu diperbaiki, sehingga dapat memberikan pelayanan yang optimal ke pada masyarakat. dan juga untuk meningkatkan pelayanan Kantor Kelurahan Tlogomas Kota Malang mengadopsi sistem Pelayanan Terpadu Satu Pintu (PTSP) sistem ini merupakan sistem dimana masyarakat hanya menemui satu loker pelayanan yang akan melayani segala urusan administrasi masyarakat. Adapun faktor pendukung pelaksanaan evaluasi Di kelurahan Tlogomas Kota Malang adanya regulasi/peraturan yang digunakan sebagai acuan dalam pengevaluasian, sarana pasarannya yang nyaman bagi pegawai kantor kelurahan, kedisiplinan pegawai yang datang sesuai jam kerja dan didukung dengan absen sidik jari sehingga kedisiplinan pegawai sangat menunjang proses pelayanan. Faktor penghambat nya ialah rasa sungkan (ketidak enakan) dalam pemberian penilaian kepada setiap pegawai dikarenakan suasana yang dibangun merupakan suasana kekeluargaan. Kesimpulannya bahwa pelayanan di kantor Kelurahan Tlogomas sudah cukup baik. Adapun saran yang dapat diberikan penulis dapat memberikan pelayanan yang maksimal, profesional, memiliki motivasi yang kuat dalam memberikan pelayanan, memberikan pendapat dan menyuarakan pendapat memiliki rasa tanggung jawab yang besar sehingga dalam pengevaluasian tercipta lah perubahanperubahan yang akan meningkatkan kualitas kinerja setiap pegawai.
\end{abstract}

Kata Kunci: evaluasi kinerja, pelayanan publik, good governance

\section{PENDAHULUAN}

Negara Indonesia adalah Negara yang memiliki perundangan-undangan yang sangat banyak dimana setiap keputusan tidak hanya keluar begitu saja melainkan ada undangundang yang menguatkan keputusan yang dikeluarkan. Salah satu dari undang-undang tersebut adalah tentang pelayanan publik. Pelayanan publik merupakan dasar dalam 
penyelenggaraan pemerintahan. Pelayanan publik sebagai indikator penting dalam penilaian kinerja pemerintahan. Baik di tingkat pusat maupun di daerah. Undang-undang nomor 25 tahun 2009 tentang pelayanan publik dalam pasal 1 ayat (1) bahwa pelayanan publik adalah kegiatan dalam rangka pemenuhan kebutuhan pelayanan sesuai dengan peraturan perundang-undangan bagi setiap warga negara dan penduduk atas barang, jasa dan/atau pelayanan administrasi yang disediakan oleh penyelenggaraan pelayanan publik.

Berdasarkan uraian dalam UU No. 25/2009 tersebut diatas memberikan penegasan bahwa pemerintah berkewajiban memberikan pelayanan dengan sebaik-baiknya kepada masyarakat. Prinsip penting dalam penyelenggara pemerintahan adalah good governance (pemerintahan yang baik). Good governance sebagai tujuan utama dalam penyelenggara pelayan kepada masyarakat. Sebagai goals, tentunya good governance membutuhkan sebuah proses penyelenggaraan pemerintahan yang berkualitas, profesional dan akuntabel. Pelayanan publik menjadi bagian penting dalam pencapaian tujuan pemerintahan yang baik. Bahkan, pelayanan publik menjadi indikator penting dalam rangka good governance.

Good governance adalah salah satu tujuan terpenting dalam penyelenggaraan pemerintahan. Setiap lembaga atau instansi pemerintah saat ini berlomba-lomba dalam melaksanakan penyelenggaraan pelayanan untuk menjadi yang terbaik dengan capaian good governance. (Hayat: 2017: 168), Tatanan pemerintah yang baik adalah memberikan kepuasan dalam bidang pelayanan publik, bersih dari korupsi, kolusi dan nepotisme, tujuan akhir dari sistem pemerintahan adalah good governance, yaitu tatanan pemerintah yang baik dalam segala aspek.

Untuk mengukur hasil dalam kondisi-kondisi pelaksanaan dan penyelidik apakah program dilaksanakan sesuai dengan apa yang diinginkan dan apabila tidak berada dalam posisi untuk menghentikan atau memperbaikinya. Penyelidikan yang diperlukan ini disebut sesuatu evaluasi.

Evaluasi dalam penggunaannya yang paling umum adalah suatu proses yang di lakukan untuk menentukan nilai (value). Dengan demikian evaluasi merupakan bagian dari setiap analisis untuk keputusan publik(moekijat:180). Salah satu instansi pemerintahan yang bisa dibilang unit terkecil dari instansi pemerintahan pusat adalah Kelurahan, dan saat ini Satuan Kerja Perangkat Daerah (SKPD) di seluruh Indonesia menggunakan pelayanan yang sangat baik demi mewujudkan tata pemerintahan yang baik. Kelurahan Tlogomas merupakan salah satu bagian dari Satuan Kerja Perangkat Daerah (SKPD) Kota Malang. Kelurahan Tlogomas adalah unit pemerintahan terkecil yang mengatur dan mengurus urusan pemerintahan dalam penyelenggaraan pemerintahan dan merupakan unit organisasi pemerintahan yang paling dekat dan berhubungan langsung dengan masyarakat dalam mewujudkan kepuasan masyarakat dengan kinerja pegawai dalam bentuk pelayanan publik yang diberikan kepada masyarakat.

Di samping itu peran kelurahan di atas menjembatani program-program pemerintah untuk di sosialisasi kan kepada masyarakat sehingga dapat dipahami dan didukung oleh masyarakat. Dan pentingnya partisipasi masyarakat dalam menciptakan dan mendukung pelayanan publik juga menjadi bagian yang tidak dapat dipisahkan.

Disadari bahwa kondisi birokrasi perintahan yang saat ini menuntut untuk menjadi lebih baik dari pada tahun-tahun sebelumnya dimana masih banyak instansi pemerintahan yang belum memenuhi standar kepuasan masyarakat. Contohnya ketidak tepatan waktu dalam melakukan penyelesaian pelayanan kepada masyarakat.

\section{TINJAUAN PUSTAKA}

Agnes Rimbawan pada tahun 2012 yang berjudul penelitian "penerapan good governance di dinas pekerjaan umum kabupaten pandeglang" tujuan penelitian ini untuk 
mengetahui bagaimanakah penerapan good governance di dinas pekerjaan umum kabupaten pandeglang dan hambatan-hambatan yang terjadi dalam proses penerapan prinsip-prinsip good governance tersebut. Berdasarkan hasil penelitian dan analisis data yang dilakukan, dalam penerapan good governance. Di Dinas Pekerjaan Umum Kabupaten Pandeglang tidak berjalan secara maksimal. Hal ini dikarenakan belum di terapkanya, seperti partisipasi dari masyarakat, transparansi yang efektif dan menyeluruh, akuntabilitas yang belum maksimal, kurangnya kualitas Sumber Daya Manusia (SDM) pemberian pelayanan kepada masyarakat yang belum efektif dan efisien, serta supremasi hukum tidak berjalan dengan efektif.

Muhammad Syafitra Arifin (2012) "efektifitas pelayanan publik di Kecamatan Maritengngae Kabupaten Sidenreng Rappang”. Adapun hasil dari penelitian ini adalah persepsi masyarakat terhadap efektifitas pelayanan publik di Kecamatan Maritengngae suda terlaksana dengan baik. Hal ini terbukti dari hasil jawaban dari para responden berdasarkan hasil penelitian dilihat dari indikator yaitu kesederhanaan, kejelasan dan kepastian, keamanan, keterbukaan ekonomis, keadilan yang merana dan ketepatan waktu. Dari semua indikator yang menunjukkan hasil responden berada pada kategori sedang. Hal ini berarti bahwa penyelenggara di kecamatan maritengngae menandakan bahwa tingkat pelayanannya suda baik namun masih perlu ditingkatkan baik dari segi kualitas maupun kuantitas nya adapun faktor-faktor yang mempengaruhi efektifitas pelayanan publik di kecamatan maritengngae yaitu sumber daya, aparatur sarana dan prasarana serta kesadaran masyarakat.

Ones Gita Crystalia (2015) "Kualitas Pelayanan Publik Dikantor Kecamatan Pengasih Kabupaten Kulon Progo". Adapun hasil dari penelitian ini adalah: kualitas pelayanan publik di Kantor Kecamatan Pengasih Kabupaten Kulon Progo dapat dinilai dari beberapa dimensi yaitu bukti fisik (tangible), kehandalan (reliability), ke tanggapan (responsiveness), jaminan (assurance), dan empati (emphaty). Faktor penghambat pelaksanaan pelayanan publik di kantor Kecamatan Pengasih Kabupaten Kulon Progo adalah kurangnya sumber daya pegawai dan masih kurangnya sarana prasarana. Sedangkan faktor pendukungnya adalah semangat yang di berikan pegawai satu sama lain, mengadakan rapat koordinasi atau semacam evaluasi setiap tiga bulan kemudian memberikan penanaman kesadaran melayani masyarakat dengan ikhlas dengan sesuai dengan hati nurani. Faktor pendukung yang lain adalah adanya fasilitas berupa alat bantu untuk memudahkan proses pelayanan.

Maya Rahmadhani R, (2016), "Evaluasi Kinerja Pelayanan Aparatur Kelurahan WayDadi Baru Pasca Pemekaran Wilayah Kelurahan Di Kota Bandar Lampung”. Dari hasil dan penelitian adalah: bahwa kinerja aparatur Kelurahan Way Dadi Baru pasca pemekaran wilayah Kelurahan di Kota Bandar Lampung sudah cukup baik, karena dalam memberikan kepedulian kepada masyarakat, aparatur cukup baik dan tidak timbul rasa ketidakadilan pada masyarakat. Adapun faktor-faktor penghambat yang menjadi masalah dalam pelaksanaan pelayanan sistem administrasi yaitu kurangnya kesadaran dan tanggungjawab pada aparatur, serta kurangnya sarana dan prasarana pendukung pelaksanaan pelayanan sistem tata pemerintahan.

\section{METODE}

\section{Jenis Dan Pendekatan Penelitian}

Metode yang digunakan dalam penelitian ini adalah metode penelitian jenis kualitatif dengan pendekatan deskriptif. Penggunaan jenis kualitatif dalam penelitian ini adalah dengan mencocokkan antara realita dengan teori yang berlaku dengan menggunakan metode deskriptif. 


\section{Lokasi Penelitian}

Tempat penelitian merupakan tempat dimana peneliti mengambil lokasi penelitian di Kantor Kelurahan Tlogomas Kota Malang Kec. Lowokwaru Provinsi Jawa Timur. Informan penelitian adalah orang yang dimanfaatkan untuk memberikan informasi tentang situasi dan kondisi latar belakang penelitian (meleong, 2006: 90).

\section{Fokus Penelitian}

Pembentukan fokus penelitian tersebut mempunyai dua tujuan yaitu: menetapkan fokus membatasi studi yang berarti dengan adanya fokus, penetuan situs penelitian yang layak, penentuan fokus secara efektif penetapan kriteria inklusi-inklusi untuk menjaring informasi yang mengalir masuk. Adapun yang menjadi fokus penelitian:

a. Evaluasi Kinerja Pegawai untuk mewujudkan Pelayanan Publik dalam perspektif good governance di Kantor Kelurahan Tlogomas Kota Malang.

$>$ Pelayanan di Kantor Kelurahan Tlogomas.

$>$ Sistem pelayanan yang terealisasi di Kelurahan Tlogomas Kota Malang.

b. Faktor pendukung dan faktor penghambat pelaksanaan Evaluasi Kinerja Pegawai untuk mewujudkan Pelayanan Publik dalam perspektif good governance di Kantor Kelurahan Tlogomas Kota Malang.

$>$ Faktor pendorong pelaksanaan Evaluasi Kinerja Pegawai untuk mewujudkan Pelayanan Publik dalam perspektif good governance di Kantor Kelurahan Tlogomas Kota Malang.

$>$ Faktor penghambat pelaksanaan Evaluasi Kinerja Pegawai untuk mewujudkan Pelayanan Publik dalam perspektif good governance di Kantor Kelurahan Tlogomas Kota Malang.

\section{Sumber Data}

Sebagaimana yang dikemukakan suharsimi arikunto bahwa sumber data adalah subjek dari mana data dapat diperoleh (suharsimi arikunto, 2006:156) sedangkan menurut lofland yang telah dikutip oleh Lexy J. Meleong (2006:157) bahwa sumber data utama dalam penelitian kualitatif adalah kata-kata dan tindakan, selebihnya data tambahan seperti dokumen dan lain-lain. Sumber data dalam penelitian ini di bagi menjadi dua yaitu:

\section{a. Data primer}

Yaitu data yang di peroleh secara langsung pada saat kita melakukan penelitian, sumber data eyang diperoleh secara langsung dari dari orang-orang atau responden yang secara sengaja dipilih untuk memperoleh data-data atau informasi yang ada relefansinya dengan permasalahan penelitian.

\section{b. Data Sekunder}

Yaitu data yang dikutip dari sumber-sumber tertentu yang di gunakan sebagai pendukung data primer sumber data sekunder ini merupakan sumber data yang melengkapi serta memperkaya sumber data primer atau sumber data sekunder ini diperoleh dari data pendukung. Yang menjadi subjek penelitian ini adalah pegawai Kelurahan Tlogomas dengan alasan bahwa pegawai Kelurahan Tlogomas yang memegang peranan penting dalam memberikan pelayanan.

\section{Teknik Pengambilan Sampling}

Dalam penelitian kualitatif ini penelitian menggunakan teknik purposive sampling. Menurut sugiyono (2016: 218) mengemukakan bahwa purposive sampling 
adalah teknik pengambilan sampel sumber data dengan pertimbangan tertentu. Pertimbangan tertentu ini, misalnya orang tersebut yang di anggap paling tahu apa yang kita harapkan, atau mungkin dia sebagai penguasa sehingga akan memudahkan peneliti menjelajahi objek/situasi sosial yang teliti, Jadi, penetuan sampling dalam penelitian kualitatif dilakukan saat penelitian mulai memasuki lapangan dan selama penelitian berlangsung (emergent sampling design). Caranya yaitu penelitian memilih orang tertentu yang dipertimbangkan akan memberikan data yang di perlukan, selanjutnya berdasarkan data atau informasi yang di peroleh dari sampel sebelumnya itu, peneliti dapat menentukan sampel lainnya yang diperhitungkan akan memberikan data lebih lengkap. (sugiyono: 2016: 218).

\section{Teknik pengumpulan data}

Dalam suatu penelitian faktor pengumpulan data merupakan suatu hal yang sangat penting guna memperoleh data yang sesuai dengan permasalahan yang diteliti. Prosedur pengumpulan data yang digunakan dalam penelitian ini ada data melalui observasi (pengamatan), interview (wawancara secara mendalam), dan analisis data dan dokumentasi.

\section{a. Observasi}

Observasi adalah cara pengambilan data dengan menggunakan pengamatan secara langsung terhadap objek yang diteliti. Dapat diteliti dari perilaku subjek (orang), objek (benda) atau kejadian sistematik tanpa adanya proses Tanya jawab dengan individu-individu yang diteliti, tujuan dari observasi adalah untuk menggambarkan sesuatu yang berhubungan dengan penelitian.

\section{b. Wawancara}

Wawancara adalah percakapan dengan maksud tertentu. Percakapan itu dilakukan oleh dua pihak, yaitu pewawancara (interviewer) yang mengajukan pertanyaan dan terwawancara (interviewee) yang memberikan jawaban atas pertanyaan. (Lexy J. Moleong, 2006:186). Adapun wawancara yang digunakan dalam penelitian ini adalah wawancara terstruktur dan wawancara tidak terstruktur. Wawancara terstruktur adalah wawancara yang ditetapkan sendiri pertanyaan-pertanyaan yang akan diajukan oleh pewawancara. Sedangkan wawancara tidak terstruktur adalah kegiatan wawancara mengalir seperti biasa, yaitu mengikuti dan menyesuaikan dengan situasi dan kondisi responden.

\section{c. Dokumentasi}

Dokumentasi berasal dari kata tertulis. Dalam melaksanakan metode dokumentasi peneliti mencari data mengenai hal-hal atau variabel yang berupa catatan, transkrip, buku, surat kabar, majalah, prasasti, notulen rapat, dan sebagainya. (Suharsimi Arikunto, 2006:206) Sedangkan dokumen adalah bahan tertulis yang dibutuhkan peneliti yang dimanfaatkan sebagai dokumen yang berarti barang-barang penguji, menafsirkan dan bukti konkret data yang diperoleh di lapangan.

\section{Keabsahan Data}

Untuk mengetahui apakah data yang dikumpulkan dari penelitian ini betul-betul suda valid dan bisa dipertanggungjawabkan, maka yang harus dilakukan peneliti adalah mengeceknya kembali secara cermat dan teliti (cross check), agar penelitian yang dilakukan tidak sia-sia yang hanya terjebak pada simbolisme. Untuk mengecek terhadap validasi temuan dari data yang di peroleh, maka langkah-langkah yang ditempuh oleh peneliti dalam mengukur keabsahan data adalah dengan menggunakan teknik-teknik berikut: 


\section{a. Observasi yang diperdalam}

Observasi ini dilakukan untuk meningkatkan intensitas ketekunan dalam melakukan pengamatan agar peneliti memperoleh data yang akurat sesuai dengan masalah yang di teliti.

\section{b. Triangulasi}

Dalam menggunakan metode triangulasi ini adalah untuk memeriksa kevalidan temuan yang memanfaatkan sesuatu yang lain diluar data ini dengan tujuan untuk keperluan pengecekan atau membandingkan data yang ada di lapangan. (Lexy J. Meleong, 2006: 330)

$>$ Triangulasi metode, cross check dengan menggunakan metode pengumpulan data yang lain atau berbeda

$>$ Triangulasi sumber, cross check terhadap para informan dan dokumen yang di temukan

$>$ Triangulasi teori, penggunaan beberapa perspektif teori untuk menjelaskan fenomena yang diteliti

Dengan menggunakan beberapa triangulasi diatas, peneliti dapat membandingkan atau mengecek balik derajat kepercayaan suatu informan yang diperoleh. Dalam konteks penelitian ini sumber data terutama wawancara tidak mencukupkan satu saja, tetapi dengan beberapa orang yang di ambil secara purposive agar data yang di peroleh benar-benar sesuai dengan realitas yang ada.

\section{c. Interpretasi}

Interpretasi adalah data yang diperoleh dipikirkan dan direnungkan kembali tentang keabsahannya.

\section{Analisis Data}

Pada hakikatnya penelitian kualitatif adalah penelitian yang bermaksud untuk memahami fenomena (fenomenologis) tentang apa yang dialami oleh subjek penelitian, seperti; perilaku, persepsi, motivasi, tindakan, dan lain-lain secara holistik dan dengan cara deskripsi dalam bentuk kata-kata dan bahasa pada suatu konteks khusus yang alamiah dan dengan memanfaatkan berbagai metode alamiah (Kirk dan Miller, Jane Richie, Bogdan dan Bikley, Guba dan Lincoln).

Spradley (1980) membagi analisis data dalam penelitian kualitatif berdasarkan tahap dalam penelitian kualitatif. Adapun ciri-cirinya sebagai berikut:
a. Analisis domain
b. Analisis taksonomi
c. Analisis komponensial
d. Analisis tema budaya

\section{Alur Penelitian}

Alur penelitian merupakan suatu prosedur yang terstruktur. Yang ingin dilakukan oleh peneliti dalam karya penelitiannya alur penelitian digunakan untuk membantu peneliti dalam melangkah ketika di lapangan dan memberikan batasan ketika penyusunan hasil dari penelitian. 


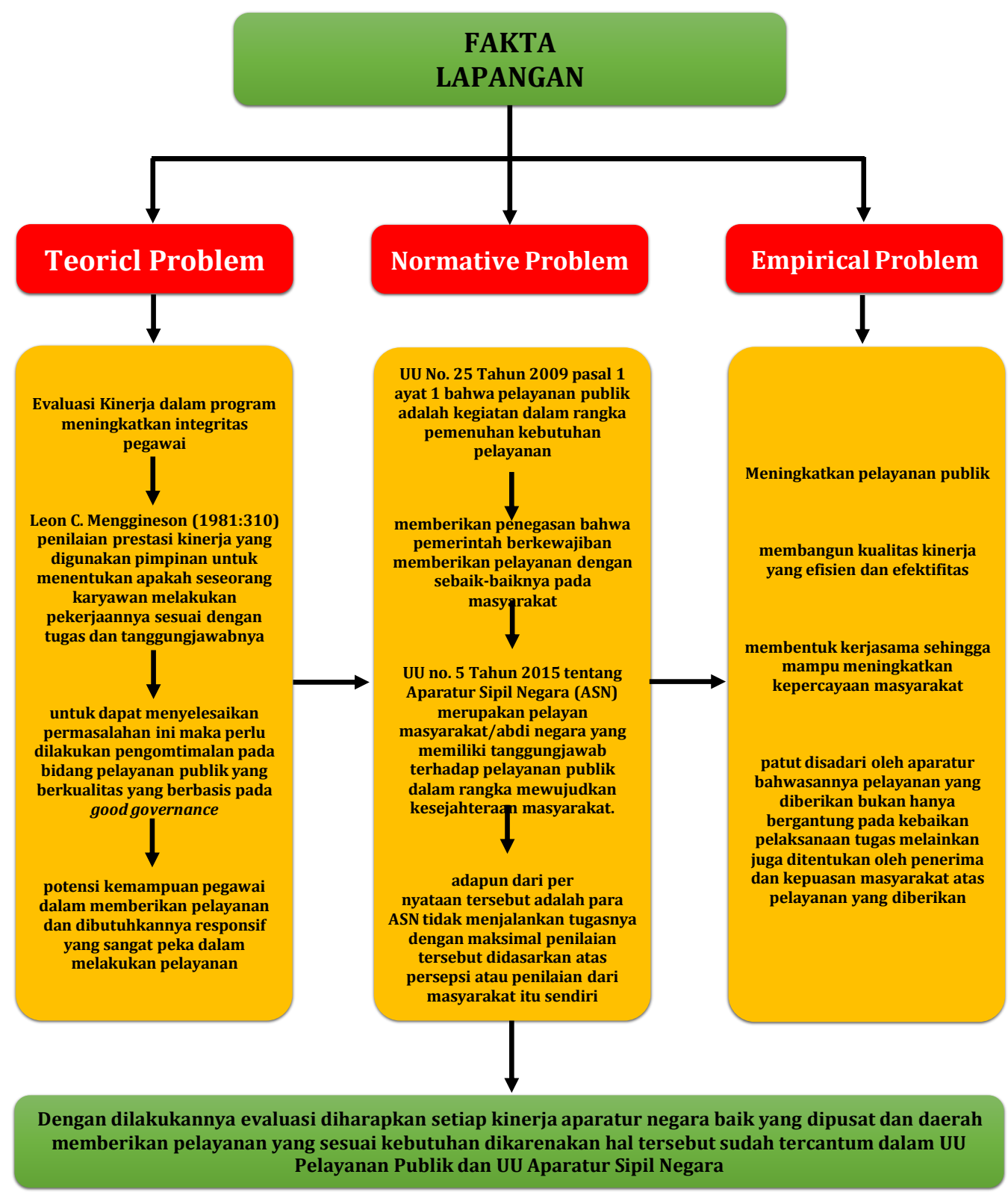

Gambar 1. Alur Penelitian

\section{HASIL}

\section{Evaluasi Kinerja Pegawai Untuk Mewujudkan Pelayanan Publik Dalam perspektif good governance di kantor Kelurahan Tlogomas}

Evaluasi kinerja adalah penilaian yang dilakukan secara sistematis untuk mengetahui hasil pekerjaan karyawan, serta memberikan tanggung jawab yang sesuai sehingga dapat melaksanakan pekerjaan yang lebih baik dimasa mendatang. Penilaian suatu kinerja pegawai dapat dilakukan dengan mengukur seberapa jauh kinerja pegawai dengan melakukan penilaian kuantitatif dan kualitatif sehingga hasil kerja yang dicapai oleh pegawai sesuai dengan yang diharapkan. Dalam melakukan penilaian ada juga yang mengutamakan sistem kekeluargaan dimana penilaian ini lebih menjunjung kebersamaan dan gotong royong dalam melakukan suatu tugas.

Tentunya dalam melakukan evaluasi juga terdapat unsur-unsur yang digunakan sebagai acuan dalam melakukan pengevaluasian penilaian pelaksanaan pekerjaan yaitu: 
kesetiaan, prestasi kerja, tanggung jawab, ketaatan kejujuran, kerja sama prakarsa dan kepemimpinan.

\section{Pelayanan Dikantor Kelurahan Tlogomas.}

Pelayanan merupakan suatu sarana yang untuk memenuhi kebutuhan masyarakat. Dimana pelayanan lah yang sangat menunjang akan ke efektifitas kinerja pegawai Adapun pelayanan yang ada Dikantor Kelurahan Tlogomas Kota Malang yaitu:

$>$ Pengurusan KTP Baru

$>$ Pengurusan Pindah Masuk

$>$ Pengurusan Pindah Keluar

$>$ Pengurusan Kartu Keluarga Baru

$>$ Pengurusan KK Karena Tambah Anggota

$>$ Pengurusan KTP Karena Hilang

$>$ Pengurusan KK Karena Rusak/Hilang

$>$ Pengurusan SKCK

$>$ Pengurusan Ijin Penelitian

$>$ Pengurusan KK karena pengurangan anggota keluarga

$>$ Pengurusan Akte Kelahiran diatas 60 hari

Pengurusan Nikah

Ada pun data diatas merupakan macam-macam pelayanan yang dilakukan di Kelurahan Tlogomas Kota Malang. Sehingga hasil observasi yang dilakukan oleh peneliti pada hari rabu, tanggal 28 februari 2018 yang menunjukkan bahwa pelayanan dikantor Kelurahan Tlogomas kota malang sudah berjalan dengan baik, dapat dilihat dari respons petugas lumayan cepat sehingga pelayanan menjadi optimal, selain pelayanan administrasi yang diberikan Kantor Kelurahan juga memberikan pelayanan yang bersifat partisipasi kepada masyarakat. yang disampaikan oleh pihak Kelurahan Tlogomas dari hasil wawancara dengan salah satu narasumber ialah Bapak Arwanto, 50 thn, selaku sekretaris Kelurahan Tlogomas:

Jadi pelayanan itu ada dua pelayanan administrasi dan pelayanan partisipasi masyarakat. Masyarakat ikut dalam suatu kegiatan itukan juga pelayanan kita karana mereka aktif untuk melaksanakan pembangunan, pelayanan administrasi, surat menyurat dan apabila ada komplain kita juga menyiapkan fasilitas kotak suara, atau menghadap saya"

Dan dalam kesempatan ini juga peneliti mewawancarai beberapa informan dari masyarakat mengenai pemberian pelayanan dikantor Kelurahan Tlogomas Kota Malang. (Bapak Sugianto, 43, tim sar kelurahan).

Menurut bapak sugianto bahwasanya pelayanan kelurahan sudah baik, dimana ia mengatakan: "iya mbak suda baik, sesuai dengan ketentuan yang diberikan, fasilitas juga semuanya sudah oke, kalau mengurus ktp juga sesuai dengan 6 hari selama jam kerja mbak, kalau surat pengantar bisa langsung mbak, pokoknya sudah sesuai cukup baik.

\section{Sistem Pelayanan yang Terealisasi di Kantor Kelurahan Tlogomas Kota Malang}

Sistem pelayanan yang terealisasi dikantor Kelurahan Tlogomas kota malang Merupakan proses pemberian pelayanan yang pada saat ini memang lebih mudah, apabila di dukung dengan sistem pelayanan yang sangat membantu terhadap 
masyarakat itu sendiri, sistem pelayanan yang sudah terealisasi di Kelurahan Tlogomas yaitu pelayanan PTSP (pelayanan terpadu satu pintu) sesuai dengan hasil observasi dari peneliti pada tanggal 28 februari 2018 bahwasanya sistem PTSP ini yang sudah diterapkan sejak 2014 sangat membantu akan proses pelayanan di kantor Kelurahan Tlogomas. Dimana masyarakat yang mengurus administrasi cukup dating kesatu loket untuk mengurus. Sehingga dalam hal ini sangat memungkinkan tidak akan adanya proses pungli terhadap masyarakat. Dan juga sesuai sesuai dengan yang disampaikan oleh pak lurah bahwasanya (Aryadi wardoyo, kelapa kelurahan).

"sisi pemerintahan saat ini menggunakan pelayanan satu pintu, sistemnya mirip dengan sistem bank. Dimana sistem pelayanan satu pintu ini disebut pelayanan terpadu satu pintu (PTSP) dimana masyarakat yang mengurus administrasi cukup mendatangi satu loket kelurahan untuk melayani seluruh kebutuhan masyarakat, sehingga dapat juga menghindari dari proses pungli".

4. Faktor Pendukung Pelaksanaan Evaluasi Kinerja Pegawai Untuk Mewujudkan Pelayanan Publik Dalam Perspektif Good Governance Di Kantor Kelurahan Tlogomas Kota Malang.

Dalam melaksanakan evaluasi kinerja pegawai tidak bisa terlepaskan dari faktorfaktor pendukung dan penghambat adapun faktor-faktor yang mempengaruhi.

Faktor pendukung

$>$ Regulasi/peraturan

$>$ Sarana prasarana

$>$ Kedisiplinan

Dalam kesempatan itu juga peneliti mewawancarai informan terkait penilaian dikantor Kelurahan Tlogomas yang juga menjadi faktor pendukung pengevaluasian seperti yang dikatakan (Aryadi wardoyo, kepala kelurahan) dalam melakukan penilaian yaitu:

"yang lebih utama dari kami mengedepankan kedisiplinan, secara umum mereka tidak ada masalah yang berarti dipekerjakan baik dikesiplinan dan sebagainya kalau pun melanggar pun pelanggaran yang kecil, dengan batas yang penuh kewajaran dan manusiawi lah, yah untuk bisa mencapai kedisiplinan itu yah, suasana treat men kerja harus di perhatikan juga antara kawan itu juga harus kompak sehingga mereka betah dan kerasan dikantor. Jadi kalau bisa saya katakan penilaian di Kelurahan Tlogomas itu seperti sistem kekeluargaan yah pak Yah kita ke depan kan disitu sehingga perangkat pekerja itu ada semangat kalau ketemu kawan-kawan dan saudaranya. Mau tidak mau kan tercapai kedisiplinan itu. Sehingga tidak ada rasa malas ke kantor.

\section{Faktor Penghambat Pelaksanaan Evaluasi Kinerja Pegawai Untuk Mewujudkan Pelayanan Publik Dalam Perspektif Good Governance di Kantor Kelurahan Tlogomas Kota Malang.}

Rasa sungkan (ketidakenakan) Merupakan ketidakenakan dalam menyampaikan penilaian sehingga dalam melakukan penilaian harus sesuai dengan peraturan yang ada dan dinilai sesuai dengan prosedurnya. Dalam kesempatan itu juga peneliti mewawancarai informan terkait faktor penghambat. Dimana dalam melakukan pengevaluasian pasti ada faktor penghambat sebagaimana yang disebutkan (Arwanto, sekretaris lurah).

"Penghambat nya adalah hubungan antara sesama pegawai contohnya saya dan sampean, kita sudah akrab terus saya nilai sampean kan juga nga enak". 


\section{Exiting Model}

Evaluasi Kinerja Pegawai Dikantor Kelurahan Tlogomas Kota Malang.

Alur pelaksanaan evaluasi kinerja pegawai.

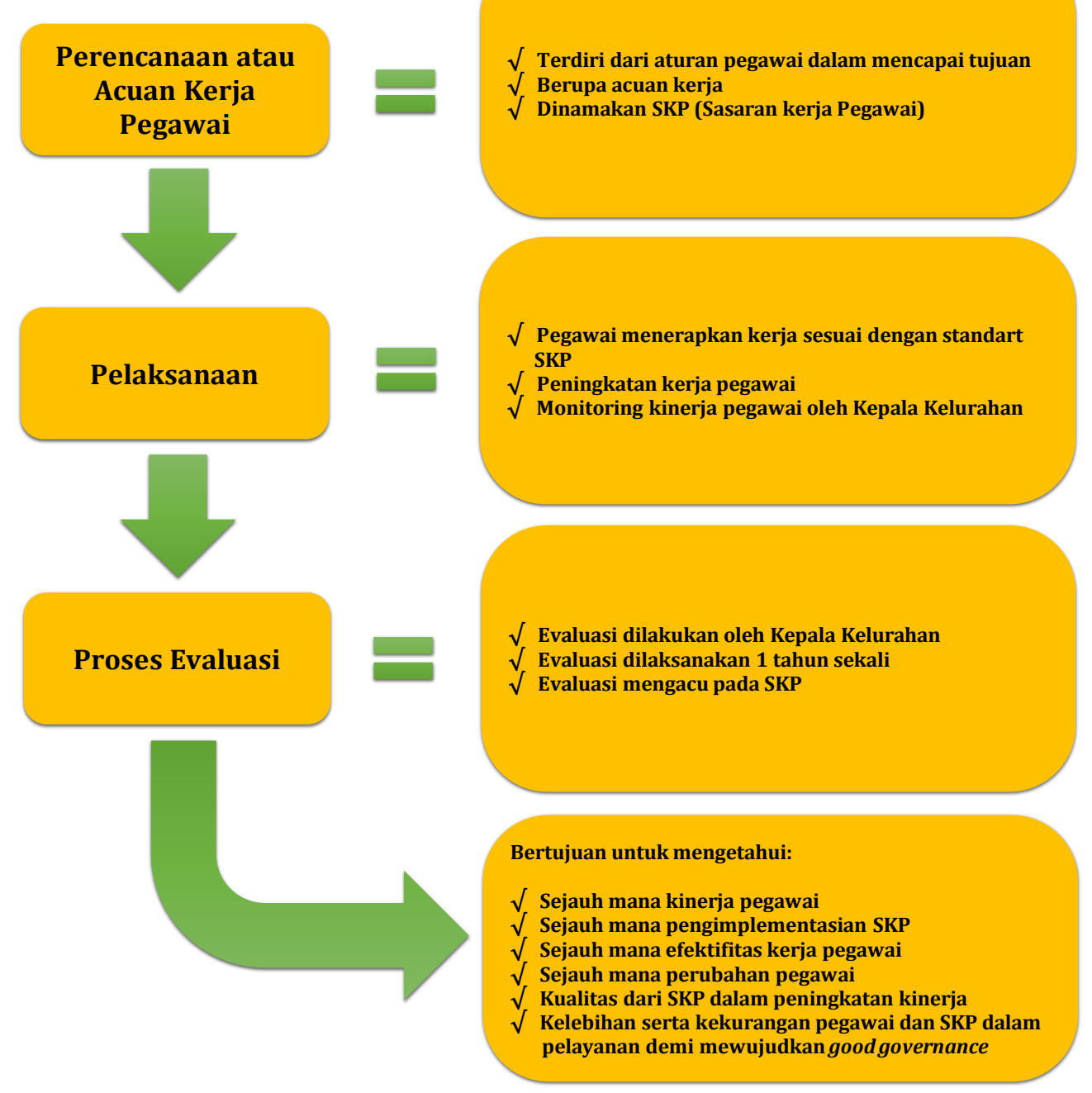

Gambar 2. Exiting model

\section{PEMBAHASAN}

\section{Evaluasi Kinerja Pegawai Untuk Mewujudkan Pelayanan Publik Dalam perspektif} good governance di kantor Kelurahan Tlogomas.

Pegawai negeri sipil mempunyai tugas pemerintahan dan pembangunan atas dasar tersebut setiap pegawai negeri sipil (PNS) dituntut untuk dapat memberikan pelayanan dengan sebaik-baiknya kepada masyarakat untuk menyelenggarakan tugas pemerintahan dan pembangunan dengan baik maka dibutuhkan pegawai negeri sipil yang profesional jujur, adil dan bertanggung jawab. Pegawai Negeri Sipil merupakan abdi negara yang memiliki tanggung jawab dalam pembangunan. Untuk menghasilkan pegawai negeri yang profesional, adil, jujur dan bertanggung jawab seperti yang diamanatkan dalam Undang-Undang pembinaan dan dalam melakukan pembinaan, harus adanya penilaian terhadap kinerja pegawai itu sendiri. Kinerja merupakan hasil kerja secara kualitas dan kuantitas yang dapat dicapai oleh seorang pegawai dalam melaksanakan tugas pokok dan fungsinya sebagai pegawai sesuai dengan tanggung jawab yang dibebankan atau diberikan kepadanya. 
Kinerja merupakan hasil kerja yang dapat dicapai oleh seorang atau kelompok orang dalam suatu organisasi, sesuai dengan wewenang dan tanggung jawab yang melekat dalam diri masing-masing dalam rangka untuk mencapai tujuan organisasi secara legal, tidak melanggar hukum dan sesuai dengan moral dan etika yang ada. (Prawirosentono, 1992,2; Sinambela, 2012). Pada penilaian kinerja pegawai dapat dilakukan dengan mengukur seberapa jauh kinerja pegawai. Penilaian kinerja merupakan serangkaian kegiatan yang dilakukan untuk menilai kinerja pegawai, yang juga dikemukan oleh Andrew E. Sikula (1981:2005) yang dikutip A.A. Anwar Prabu Mangkunegara (2000:69) mengemukakan bahwa "penilaian pegawai merupakan evaluasi yang sistematis dari pekerjaan pegawai dan potensi yang dapat dikembangkan. Penilaian dalam proses penafsiran atau penentuan nilai, kualitas atau status dari beberapa objek orang ataupun sesuatu (barang)".

Kualitas yang di hasilkan dalam pelayanan publik merupakan inti dari sebuah kinerja pelayanan. Kinerja pelayanan merupakan poin penting dalam penyelenggaraan pelayanan publik. Kualitas pelayanan publik menjadi indikator keberhasilan pelayanan publik yang diberikan. Kualitas pelayanan publik merupakan barometer bahwa pelayanan yang diberikan sesuai dengan ketentuan perundang-undangan yang berlaku.

Pelayanan publik juga merupakan salah satu penunjang terciptanya good governance (pemerintahan yang baik) dimana good governance sebagai tujuan utama dalam penyelenggaraan pelayanan kepada masyarakat. Sebagai goals, tentunya good governance membutuhkan sebuah proses penyelenggaraan pemerintah yang berkualitas, profesional dan akuntabel.

\section{Pelayanan Dikantor Kelurahan Tlogomas}

Tidak dapat di pungkiri, bahwa untuk menghasilkan kualitas pelayanan publik tidaklah mudah. Banyak tantangan yang dihadapi, baik oleh individu pegawai bahkan organisasi yang menaunginya, terutama terkait hal komitmen dan konsistensi serta orientasi yang menjadi tujuan utama dalam pelayanan publik. Mulai dari aspek rekrutmen aparatur, penataan dan pembinaan sampai dengan pengendalian dan evaluasi kinerja. Struktur yang dibangun untuk memaksimalkan pelayanan. Evaluasi kinerja pelayanan menjadi catatan penting bagi pemerintah terkhusus nya Kantor Kelurahan Tlogomas sebagai upaya untuk mewujudkan pemerintahan yang baik (good governance).

Inovasi yang inovatif terus ditingkatkan oleh Kelurahan Tlogomas demi mencapai pelayanan yang berkualitas dan mampu memenuhi kebutuhan masyarakat. Salah satu strategi Kelurahan Tlogomas dalam menuntaskan persoalan tersebut ialah, kantor kelurahan mengadopsi sistem PTSP (Pelayanan Terpadu Satu Pintu) hal ini diterapkan agar mampu memaksimalkan pelayanan yang diberikan kepada masyarakat. Kelurahan Tlogomas menerapkan sistem pelayanan PTSP dikarenakan mampu meminimalisir proses administrasi pelayanan yang kita kenal cukup rumit. Bapak Aryadi Wardoyo selaku Kepala Kelurahan Tlogomas menyatakan PTSP diterapkan dikarenakan bergambar pada sistem bank di Indonesia yang notabene nya menjadi sebuah penerapan ataupun pengimplementasian sistem yang sangat di ideal dalam konsep pelayanan. Hal lain yang patut kita apresiasi dengan diterapkannya sistem PTSP ialah mampu meminimalisir perilaku pungli yang kita kenal sangat meresahkan dan mendiskriminasikan masyarakat yang telah menjamur di seluruh lembaga pemerintah pusat hingga pemerintah Desa. 


\section{Sistem Pelayanan yang Terealisasi di Kantor Kelurahan Tlogomas Kota Malang.}

Sejatinya pelaksanaan pelayanan publik dalam perspektif good governance harus didukung dengan sistem yang ideal agar mampu menunjang kualitas serta kuantitas terhadap pelaksanaannya. Aspek pelaksanaan tidak akan bisa berjalan mulus dan sesuai rencana tanpa didukung dengan sistem yang memadai dan mampu menunjang pelaksanaan pelayan publik. Dengan diterapkannya sistem tersebut sebagai pedoman ataupun landasan dalam pelaksanaan pelayanan publik mampu meningkatkan presentasi ataupun peluang keberhasilan dalam pencapaian good governance. Maka dari itu khususnya Kelurahan Tlogomas mengkonsumsi salah satu sistem demi menunjang serta meningkatkan pencapaian nya terhadap pelayanan khususnya dalam konteks pelayanan publik, yang dimana sistem tersebut berupa sistem Pelayanan Terpadu Satu Pintu (PTSP).

Respond yang baik dari masyarakat maupun aparat pemerintah di beberapa kabupaten/kota terhadap keberadaan pelayanan terpadu menjadi alasan yang cukup kuat oleh pemerintah Kelurahan Tlogomas.

Kantor Kelurahan Tlogomas menerapkan sistem pelayanan PTSP (Pelayanan terpadu satu pintu) yang merupakan satu kesatuan proses pengelolaan pelayanan terhadap beberapa jenis pelayanan yang dilakukan secara berintegrasi dalam satu tempat, baik secara fisik maupun virtual. Dewasa nya kantor Kelurahan Tlogomas telah mengimplementasikan sistem PTSP (pelayanan terpadu satu pintu) yang dikatakan oleh Aryadi widodo selaku kepala Kelurahan Tlogomas Kota Malang, merupakan sistem yang ideal dimana dapat menunjang keberhasilan dalam pencapaian good governance, maka dari itu kantor Kelurahan Tlogomas menggunakan sistem PTSP, sistem PTSP di kantor Kelurahan Tlogomas Kota Malang diimplementasikan pada tahun 2014.

\section{Faktor Pendukung Pelaksanaan Evaluasi Kinerja Pegawai Untuk Mewujudkan Pelayanan Publik Dalam Perspektif Good Governance Di Kantor Kelurahan Tlogomas Kota Malang.}

Tentunya ada kinerja pegawai yang harus dievaluasi untuk memperbaiki kinerja yang sebelumnya dan dalam proses evaluasi pasti memiliki konsep penilaian tersendiri, sehingga dalam lingkungan pegawai negeri sipil disebut dengan penilaian pelaksanaan pekerjaan. Apabila dilakukan dengan benar sesuai peraturan, hal ini akan memberikan manfaat yang penting bagi pegawai yang dinilai, penilai dan departemen kepegawaian, serta organisasi. Dan setiap atasan pegawai harus menilai setiap kinerja bawahannya sehingga memiliki gambaran tentang hasil kerja nyata pegawai, dengan itu dapat ditentukan juga tindakan dan kebijakan apa yang akan dilakukan ke depannya.

Instansi pemerintah di daerah maupun di pusat setiap tahunnya akan melakukan evaluasi sesuai dengan peraturan yang diterapkan oleh instansi masing-masing sehingga menghasilkan suatu kebijakan yang akan memperbaiki kinerja pegawai sebelumnya. Begitu juga kantor kelurahan Tlogomas kota Malang melakukan evaluasi sesuai dengan regulasi/peraturan yang ditetapkan oleh Kelurahan Tlogomas itu sendiri, akan tetapi kantor Kelurahan Tlogomas selain memiliki peraturan dalam melakukan evaluasi mereka juga mengedepankan sistem evaluasi kekeluargaan, dimana faktor inilah yang mendukung efektifitas dalam memberikan pelayanan kepada masyarakat dan juga fasilitas, kenyamanan, kedisiplinan dan saling menghargai menjadi faktor pendukung dalam melakukan evaluasi. Dengan melakukan evaluasi kekeluargaan akan lebih mempererat satu sama lain serta lebih mengenal kelebihan dan kekurangan setiap pegawai. 


\section{Faktor Penghambat Pelaksanaan Evaluasi Kinerja Pegawai Untuk Mewujudkan Pelayanan Publik Dalam Perspektif Good Governance di Kantor Kelurahan Tlogomas Kota Malang.}

Faktor penghambat dalam proses evaluasi kinerja diantaranya, timbulnya rasa sungkan (ketidakenakan) dalam menyampaikan pendapat mengenai sebuah kinerja sehingga proses penilaian pelaksanaan pekerjaan tidak dapat dilakukan dengan optimal dan ini merupakan faktor utama yang melatar belakangi dari terhambat nya penilaian kinerja di kantor kelurahan Tlogomas.

Dalam sebuah kegiatan sosial secara formal maupun non formal hal wajar jika para pegawai pemerintah membangun kedekatan secara emosional agar setiap proses yang dilakukan dapat memudahkan beberapa pihak khususnya dalam konteks komunikasi. Namun jika tidak dilandasi dengan semangat kerja yang akuntabel serta menjunjung tinggi profesionalitas dalam berkerja maka akan mempengaruhi kualitas kinerja pegawai tersebut. Belum lagi jika kita benturkan dengan evaluasi kinerja para pegawai yang sangat harus menjunjung profesionalitas dalam pengevaluasian, akan berimbas pada kualitas dari hasil evaluasi tersebut yang cenderung hasilnya hanya berprinsip kekeluargaan yang biasa kita sebut dengan nepotisme. Persoalan lain yang terkena dampak pada kondisi tersebut ialah tidak adanya kemajuan secara signifikan terhadap kinerja pegawai serta permasalahan-permasalahan yang sulit untuk bisa diatasi. Dikarenakan hasil dari evaluasi tersebut adalah landasan serta point-point yang menjadi variabel demi meningkatkan kinerja pegawai dalam konteks pelayanan hingga mewujudkan pemerintahan yang berstandar good governance.

\section{Rekomendasi Model}

Rekomendasi Model Evaluasi Kinerja Pegawai Di Kelurahan Tlogomas. Evaluasi kinerja bertujuan untuk memperbaiki dan meningkatkan kualitas kinerja pegawai dimana dengan mengevaluasi kinerja pegawai merupakan kegiatan tahunan yang dilakukan untuk mengetahui sejauh mana peningkatan kinerja yang telah di capai.

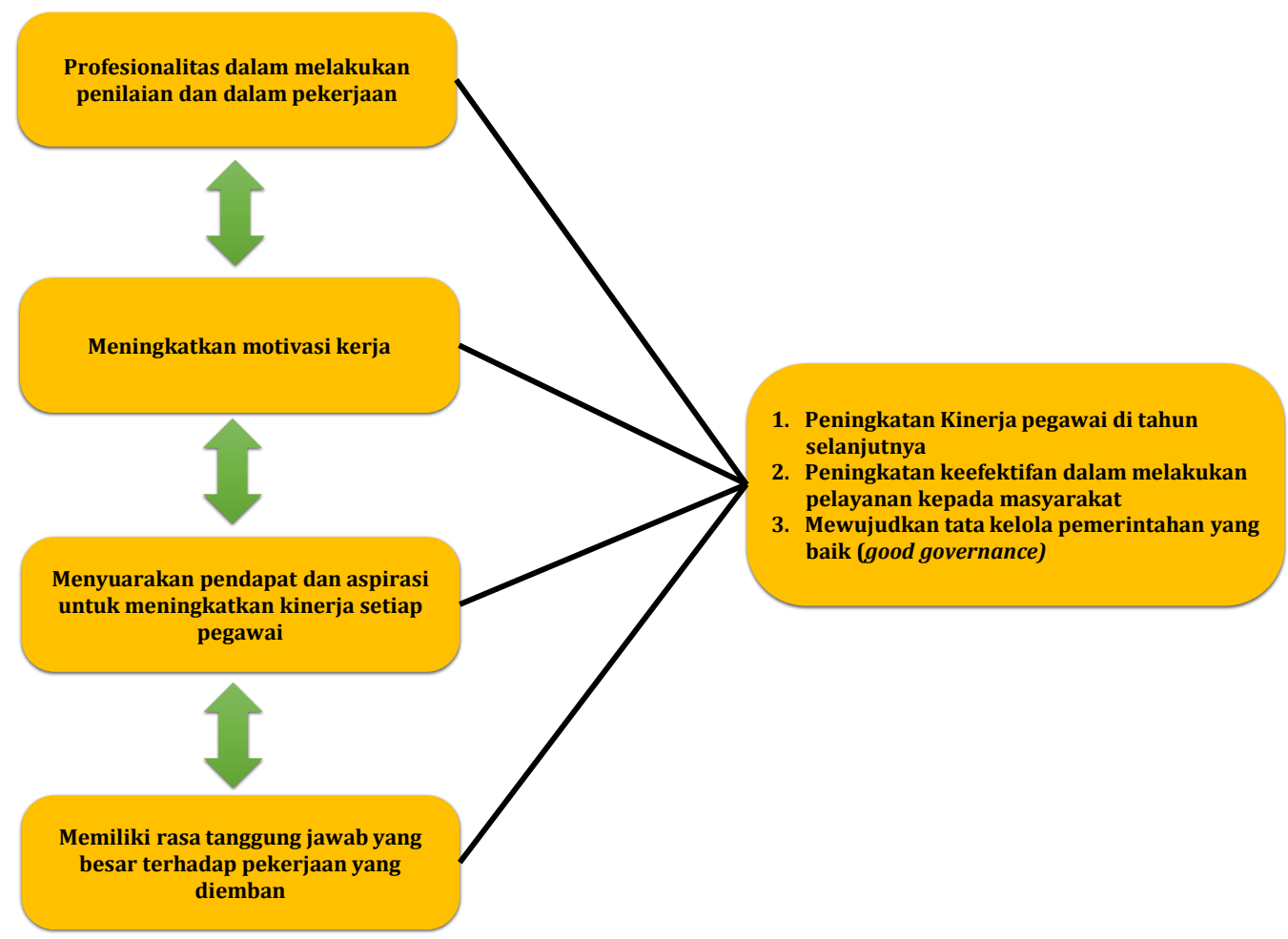

Gambar 3. Rekomendasi model 


\section{KESIMPULAN}

Evaluasi kinerja pegawai untuk mewujudkan pelayanan publik dalam perspektif good governance di kantor Kelurahan Tlogomas Kota Malang. Evaluasi kinerja pegawai dalam pelaksanaan pelayanan dapat disimpulkan bahwa dilihat dari fokus yang ada maka dapat diketahui ada hasil yang baik. Namun ada juga hal-hal yang harus diperbaiki dan beberapa fokus dapat disimpulkan bahwa:

1. Pelayanan Dikantor Kelurahan Tlogomas. Pelayanan yang disediakan di kantor Kelurahan Tlogomas merupakan pelayanan yang sangat dibutuhkan oleh masyarakat. Dimana pelayanan yang dilakukan di kantor kelurahan menunjukkan pelayanan yang berjalan dengan cukup baik, akan tetapi ada kendala-kendala yang tetap harus dibenahi. Agar dapat meningkatkan ke efektifitas pelayanan yang pada akhirnya akan mewujudkan tata kelola pemerintahan yang baik.

2. Sistem pelayanan yang terealisasi dikantor Kelurahan Tlogomas. Adapun sistem yang digunakan di kantor Kelurahan Tlogomas yaitu pelayanan terpadu satu pintu (PTSP). Dimana pelayanan terpadu satu pintu ini sangat membantu masyarakat dalam pengurusan administrasi. yang hanya mendatangi satu loket kelurahan untuk mengurus seluruh kebutuhan masyarakat. Dan juga akan menghindari proses pungli.

3. Faktor pendukung dalam melakukan evaluasi kinerja pegawai. Dalam melakukan evaluasi tidak terlepas dari faktor pendukung dan penghambat dimana faktor pendukung yaitu adanya: regulasi/peraturan yang dimana peraturan ini menjadi faktor pendukung yang mengatur dan mengendalikan kinerja pegawai dengan aturan yang berlaku. Sarana/prasana juga menjadi faktor pendukung yang akan memberikan kenyamanan pada saat pelaksanaan pengevaluasian sehingga berjalan lancar. Dan juga kedisiplinan menjadi faktor pendukung dalam pelaksanaan evaluasi dikarenakan pegawai sudah berada dikantor sesuai dengan jam kerja dan didukung juga dengan adanya absen sidik jari. Sehingga kedisiplinan para pegawai sangat menunjang akan proses pelayanan.

4. Faktor penghambat dalam pelaksanaan evaluasi kinerja pegawai. Ialah rasa sungkan (ketidak enakan) sesama pegawai dalam melakukan penilaian sehingga penilaian tidak dapat dilakukan dengan optimal.

Dari beberapa fokus diatas bahwasanya evaluasi kinerja pegawai dapat mewujudkan kualitas yang pada akhirnya akan membantu peningkatan kinerja pegawai baik dalam pembangunan dan pelayanan. Pelayanan public juga merupakan salah satu penunjang terciptanya good governance (pemerintahan yang baik) dimana good governance sebagai tujuan utama dalam penyelenggaraan pelayanan kepada masyarakat. Sebagai goals, tentunya good governance membutuhkan proses penyelenggara pemerintah yang berkualitas, professional dan akuntebel.

\section{SARAN}

Evaluasi kinerja merupakan penilaian suatu kinerja yang mewujudkan kualitas pekerjaan di masa yang akan datang. Dimana evaluasi ini sangat membantu akan peningkatan kinerja pegawai. Adapun hal-hal yang harus dikembangkan dalam pengevaluasian, sikap propesionalitas, motivasi yang sangat kuat, memberikan pendapat dan menyuarakan pendapat memiliki rasa tanggung jawab yang besar sehingga dalam pengevaluasian tercipta lah perubahan-perubahan yang akan meningkatkan kualitas kinerja setiap pegawai. Dengan meningkatnya kualitas kinerja secara garis besar akan terciptanya tata kelola yang baik dikepemerintahan. 


\section{DAFTAR RUJUKAN}

Buku

Dunn N. William, 2000. Pengantar analisis kebijakan publik, Yogyakarta: Gadjah Mada University Press.

Hayat, 2017. Manajemen pelayanan publik, malang: Rajawali Pers

Hardiyansyah, 2012. Sistem administrasi dan manajemen sumber daya manusia sektor publik dalam perspektif otonomi daerah. Yogyakarta: Gava Media.

Moleong, J. lexy. 2006. Metodelogy Penelitian Kualitatif, Bandung: PT. Remaja Rosdakarya Bandung.

Moekijat, Drs. Analisis Kebijakan Publik. Bandung: Mandar Maju.

Mangkunegara, A.A. Anwar Prabu. 2005. Evaluasi kinerja SDM. Bandung: Refika Aditama.

Muhammad, fadel. 2008. Reinventing local Government. Jakarta: Gremedia.

Sedarmayanti. 2009. Reformasi administrasi publik reformasi birokrasi dan ke pimpinan masa depan. Bandung: Refika Aditama.

Sugiyono. 2016. Metode penelitian kuantitatif, kualitatif dan R\&D. Bandung: Alfabeta

Santosa. Pandji. 2008. Administrasi publik teori dan aplikasi good governance. Bandung: Refika Aditama.

Jurnal Dan Skripsi

Ayu Amira Rosyada. 2016. Analisis penerapan prinsip good governance dalam rangka pelayanan publik di badan pelayanan perizinan terpadu satu pintu di kota Samarinda,

Agnes Rimbawan (2012) "penerapan good governance di dinas pekerjaan umum kabupaten pandeglang" Banten FISIP Universitas Sultan Ageng Tirtayasa.

Abdul halik. 2014. Kajian pengembangan kebijakan pelayanan terpadu satu pintu (PTSP) melalui perspektif indikator kinerja (IKU). JBP (jurnal bina praja)

Gita, Ones. 2015 Kualitas Pelayanan Publik Di Kantor Kecamatan Pengasih Kabupaten Kulon Progo. Yogyakarta: Fakultas Ekonomi, Universitas Negeri Yogyakarta.

Ita nurul khotimah. 2015. Penerapan disiplin kinerja pegawai dalam rangka meningkatkan mutu kinerja pegawai negeri sipil. Jurnal publik of administration. Vol-VI No.01.2015

Indra setiawan (2016) "penerapan prinsip-prinsip Good governance terhadap efektifitas kerja pegawai Bimamarga dan pematusan" Surabaya: STESIA, Sekolah Tinggi Ilmu Ekonomi Indonesia.

Muhammad Syarifah Arifin (2012) "Efektifitas Pelayanan Publik Di Kecamatan Maritengngae Kabupaten Sidenreng Rappang" Makassar: FISIP, Universitas Hasanuddin.

Maya Rahmadhani R. 2016. Evaluasi kinerja pelayanan aparatur kelurahan way dadi baru pasca pemekaran wilayah kelurahan di kota bandar lampung.

Dokumen

UU. No 25 tahun 2009 tentang pelayanan publik dalam pasal 1 ayat (1)

UU No. 5 Tahun 2015 tentang Aparatur sipil Negara (ASN)

Menteri Pemberdayaan Aparatur Negara (KEPMENPAN) No. 63/KEP/M.PAN/7/2003

Peraturan Presiden Republik Indonesia No. 7 Tahun 2005 Tentang Rencana Pembangunan Jangkah Menengah Nasional Tahun 2004-2009

Peraturan Pemerintah Republik Indonesia Nomor 10 Tahun 1979 Penilaian Pelaksanaan

Pekerjaan Pegawai Negeri Sipil

Perundang-Undangan No.23 Tahun 2014 Tentang Peraturan Daerah

Permandagri No 24 Tahun 2006 Tentang Pedoman Penyelenggaraan Pelayanan Terpadu

Satu Pintu 